\title{
How will I be when I will grow up? The importance of psychological intervention in pediatric patients to prevent symptoms from becoming chronical
}

\author{
F. Craig ${ }^{1}$, C. Bellintani' ${ }^{2}$, S. Goffredo ${ }^{1}, 3$ \\ ${ }^{1}$ Dipartimento di Scienze Mediche di Base, Neuroscienze e Organi di Senso, Università di Bari, Italy; \\ 2Dipartimento di Reumatologia, Università degli Studi di Milano, Italy; \\ ${ }^{3}$ Clinical Psychologist and Psychotherapist, London, UK
}

\begin{abstract}
SUMMARY
Psychological discomforts in pediatric patients, if not identified, and considered as personality traits can lead to abnormalities in the development. Identifying psychological problems and treating them with psychological intervention could avoid the raise of psychological disease in adulthood. The aim of this study is to evaluate the perception of self-image and interpersonal relationships of children affected by juvenile idiopathic arthritis (chronic pathology); to compare those data with those published in a previous research about enuretic children (functional pathology) and children affected by cleft palate (organic pathology).

Forty children were tested using two Graphic Projective Tests: Machover test (Human Figure Drawing Test) and Corman test (Family Drawing Test) in order to assess specific disorders of their personality through the self-image perception and the emotional relationships with other members of family.

Children affected by juvenile idiopathic arthritis show problems about the contact with the external world, underestimation of himself and inadequate perception of himself, exactly like children affected by enuresis and cleft lip and palate.

Situation of discomfort, if not taken in consideration and seen as personality traits could easily become an emotional and behavioral chronic psychological disease.
\end{abstract}

Key words: Juvenile idiopathic arthritis, Enuresis, Cleft lip and palate, Self-perception, Interpersonal relationships.

Reumatismo, 2013; 65 (5): 231-239

\section{INTRODUCTION}

Tienting he self-perception and the etero-perception of children, as patients could be negatively affected by the combination of features regarding family dinamics, personalities of parents and their aptitude toward the disease. Then, the risk to develop emotional problems such as anxiety, depression, contentiousness and behavioral problems, such as social withdrawal or relational difficulty rises steadily (1).

These risks become much more likely with the hospitalizations. It is known that hospitalization increases the possibility of manifestations of the symptoms of anxiety and depression (2). Finding out the symptoms is crucial to organize an immediate intervention in childhood, especially in the phase of admission. It's important as well not to confuse those symptoms as personality traits to avoid their personality is developed according to those symptoms.

\section{Purpose of the study}

Considered those premises, our study aims to evaluate the perception of the self-image and of the social relationships of children affected by juvenile idiopathic arthritis (JIA) and to compare them to those demonstrated by children suffering from functional pathology (enuresis) and from a congenital pathology (cleft lip and palate) (3). The identification of the specific disorder of these children and the comparison with other pathologies would allow a deeper knowledge of the psychological problems linked to the alteration of the self-image
Corresponding author: Anna Rita Carone Psicologia Generale e Clinica Dipartimento di Scienze Mediche di Base Neuroscienze ed Organi di Senso Università di Bari

Piazza Giulio Cesare, 11 - 70124 Bari, Italy E-mail: annarita.carone@uniba.it annaritacarone@gmail.com 
due to idiopathic arthritis and so to find out specific patterns of intervention (4). The immediate identification of a psychological syndrome linked to such disorders, could be crucial for the correct intervent. Furthermore, it would avoid these problems to become chronic.

\section{MATERIALS AND METHODS}

\section{Test's administration procedures}

The study was approved by local research ethics committees at the hospitals concerned. Eligible families were contacted by a letter to explain the study, inviting them in participating at the next appointment at the Out-patient Department. Written consent was obtained. The choice of methods was based on the following criteria:

1) internationally acknowledge methods;

2) documented reliability and validity;

3) appropriate to the concerned age group;

4) closely related to the aims of the study. All patients had been tested using two tests. We decided to use the Graphic Projective Tests, really useful in the evaluation of the psycho-affective development in childhood. The test consisted of asking the child to draw a person (Machover test) (5), and to draw a family (Corman test) (6). The characteristics of the sketch had been analyzed by 2 independent psychologists, not involved in the administration of the tests.

\section{Characteristics of the sample}

Forty patients, 27 female and 13 male, were included in the study. Mean age of the children was 7.5 , range 5 to 17 years. They were all white and they had been recruited at the Outpatient department of Rheumatology of University of Milan. Enuretic children were 56, 28 male and 28 female, aged between 5 and 14 years (mean 6.7), all white, recruited at the Out-patient Department of Pediatrics of the University of Bari. Children affected by cleft lip and palate were 22, 13 male and 9 female, aged between 5 and 16 years (mean 7.2), all white, recruited at the Out-patient Department of Dentistry of University of Bari (Tab. I).

\section{PSYCHOLOGICAL MEASURES}

\section{Test of K. Machover}

Human Figure Drawing Test appraises the personal and social image, the identification and child's relationship with himself based on the projection of the child's image of himself, that is to the psycho-phenomenal life of the inner self (7).

The Human Figure Drawing Test is based on the representation of the human figure. The principle of the interpretation of this test is that the produced sketch is the projection of the image of himself.

The human figure drawn it is the child himself. It's done unconsciously and therefore the perception of one's body schema and desires that accompany it. Usually you can detect similarities between the drawn man and features of who designed it (8).

The first thing to consider is the sex of the first drawn figure. Usually people draw a figure of the same sex. Ada Abraham (1963), in a study carried out with 681 boys and 658 girls aged 6 to 17 years, found that a picture is drawn of the same sex in $78.5 \%$ of cases (the difference between males and females was not statistically significant). In turn, Levy (1950) states that in 5000 subjects examined, $87 \%$ for first drew a figure that corresponds to their sex, and of $16 \mathrm{ho}-$

Table I - Characteristics of the samples.

\begin{tabular}{|l|l|l|l|l|l|l|}
\hline Disease & Subjects & $\begin{array}{l}\text { Range } \\
\text { of age }\end{array}$ & Mean age & Gender (M, F) & Ethnic group & Department \\
\hline $\begin{array}{l}\text { Juvenile } \\
\text { rheumatoid arthritis }\end{array}$ & 40 & $5-17$ & 7.5 & 13,27 & White & $\begin{array}{l}\text { Out-patient department } \\
\text { of Rheumatology, Milan }\end{array}$ \\
\hline Enuresis & 56 & $5-14$ & 6.7 & 28,28 & White & $\begin{array}{l}\text { Out-patient Department } \\
\text { of Pediatrics, Bari }\end{array}$ \\
\hline Cleft lip and palate & 22 & $5-16$ & 7.2 & 13,9 & White & $\begin{array}{l}\text { Out-patient department } \\
\text { of Dentistry, Bari }\end{array}$ \\
\hline
\end{tabular}


mosexuals in the group, 13 drew a figure of the opposite sex. This does not mean that anyone who designs a figure of the opposite sex just is homosexual. However, when this happens it might mean there is a difficulty index of gender identification, homosexuality or bisexuality or, more often, a conflict in the acceptance of their socio-sexual roles (gender identification or confusion or strong attachment to the submission parent or a person of the opposite sex) (9).

The items evaluated by psychologists were:

1) identification: the sex of the first drawn figure is considered;

2) dimension of the head: the head represents the conscious nucleus of the person;

3) eyes: organ of the light and the conscience, the contact between the most intimate part of the subject and the external world;

4) mouth: it is the center of the impulses (erotic-oral impulses and aggressiveoral impulses);

5) upper limbs and hands: they are the tools to explore the environments and to establish a contact with the surrounding world;

6) lower limbs: they are the symbol of movements, and so their aptitude toward the environment.

\section{Test of L. Corman}

Family Drawing Test shows the representation of the family dynamics, the child's relationships with the members of the family, and therefore the emotional-relational relationship with the others (relational and psycho-social phenomenological life). The Family Drawing Test allows investigating how the child lives his relationships with the family. He has been asked Draw a family of invention. The child freely projects in the drawn his feelings, conflicts, desires, preferences, fears towards his relatives, letting us know what he really feels, which not always agree with his conscious statements (10). The items evaluated by the psychologists were:

1) valorised figure: the first figure drawn usually represents the mostly valorized character of the family;
2) underestimate figure: the last figure drawn, of small dimensions, in a defective way, usually represents the most underestimated character of the family. This figure shows the disapproval or the refusal toward a member of the family;

3) position of the subject: the child drawn among his parents means he is very cuddled; while if it is drawn close to the mother or to the father, it underlines the oedipal situation of the child that directs his own affectivity toward the parent of the opposite sex and identify himself with the one of the same sex.

\section{RESULTS}

Data are expressed in frequencies and in percentages of frequencies. The G-test was used to analyze different correlations. In statistics, $G$-tests are likelihood-ratio or maximum likelihood statistical significance tests that are increasingly being used in situations where chi-square tests were previously recommended.

The $95 \%$ confidence intervals were calculated for the differences; in order to reduce the risk of making type 1 errors due to multiple comparisons, a corrected alpha level of 0.01 was chosen, otherwise the significance level was set at $\mathrm{P}<0.005$.

The Statistical Package for the Social Science (SPSS 14.0; IBM Corp., Armonk, NY, USA) statistics program for Windows was used for statistical analyses.

\section{Qualitative analysis of the Human Figure Drawing Test}

The results were qualitatively analyzed according to the following parameters:

1) Identification: the sex of the first drawn figure was considered;

2) Head: control of the impulses and the social relationships;

3) Eyes: intimate contact with the external world;

4) Mouth: real and affective nutrition;

5) Upper limbs and hands: contact with the surrounding environment;

6) Lower limbs: movements toward the environment. 
Children with juvenile idiopathic arthritis

- Identification: $75 \%$ shows a good identification, drawing first a figure of their own sex. It can't be underestimated that $25 \%$ of the subjects have shown difficulty in the identification, drawing first a figure of the opposite sex.

- Head: $75 \%$ of the subjects have drawn a belt that separated the superior part of the trunk from the pelvic zone, pointing out a missed integration among sexuality and affectivity.

- Eyes: $50 \%$ of the subjects revealed a difficulty of contact with the external world drawing closed eyes.

- Mouth: there aren't descriptive reliefs in the sample.

- Lower limbs: $50 \%$ of the subjects have drawn the feet directed in opposite direction which points out the massive presence of ambivalent feelings related to the indecision to advance, to demote, to run away or to be firm. Those date were compared with previous date about children suffering from enuresis and children suffering from cleft lip and palate.

\section{Enuretic children}

- Identification: $99.5 \%$ of children have drawn a figure of the their own sex.

- Head: $14 \%$ of children drew a very big head, indicator of a massive activity of imagination that might lead to anxiety and inadequate social adaptation. $45 \%$ of children have drawn a head of normal size.

- Eyes: $23 \%$ of children have drawn big eyes with pupil, typical of children that feel criticized and controlled. $0,05 \%$ of children have drawn closed eyes, typical of narcissistic subjects, closed in their own world and focused on the inner self; $0.04 \%$ of children drew small eyes with pupil, typical of the children that don't want to see and want to relate the less possible to the reality. $11 \%$ of children have drawn eyes without pupil, sign of emotional immaturity and dependence; $14 \%$ of children have drawn eyes of normal size.

- Mouth: 29\% of children have drawn a mouth with a thin line oriented upward or closed, which shows the desire to be approved and gratified by others.
- Upper limbs and hands: $0.12 \%$ of children have drawn very long arms, index of aggressiveness towards the environment and of desire of contact with the others. $0.04 \%$ of children have drawn short arms pointing out a lack of energy, incapacity to deal with difficulties, low self-esteem. $0.9 \%$ of children have drawn rigid arms fixed to the body, sign of rigidity and passivity.

- Lower limbs: $0.05 \%$ of children have drawn too long legs, showing the presence of autonomy; $11 \%$ of children have drawn too much small legs that could prevent the natural movements and therefore they point out psychophysics paralysis; $0.04 \%$ of children have omitted the legs, highlighting the lack of support they are able to give to himself in order to overcome all the difficulties interposed along the road of their life.

Half of the sample expressed the need to establish more open social relationships (indicating the face as the better part of the body), while the other half expressed the need of autonomy (indicating the legs as the worst part of the body).

\section{Children with cleft palate and lips}

- Identification: all the subjects have shown to have a good identification drawing first a figure of his/her own sex.

- Head: $50 \%$ of the subjects showed difficulty of autonomy and support to move and to overcome the difficulties, drawing the trunk and the legs brims and rigid.

- Eyes: $80 \%$ of the sample has revealed difficulty in the contact with the external world, drawing closed eyes or skipping the hands and the feet.

- Mouth: $50 \%$ of the subjects have drawn the mouth with a brief line, simple, with shut lips, revealing a repression of the oral aggressiveness.

- Lower limbs: $30 \%$ of the subjects have drawn the legs as standing at attention pointing out tensions and rigidity.

Children with JIA have good sexual identification, as well as children with cleft lip and enuresis. Although they don't seem to have a good integration between affectivity and sexuality. As already found out about enuretic and cleft palate children there is a 
great difficulty of contact with the outside world.

Most of them draw closed eyes, which is typical of children closed in their own world and focused on the inner self. The half of the sample affected by cleft lip and palate has shown difficulties in the contact with the external world, drawing closed eyes or skipping the hands and the feet, or drawing big eyes with pupils, which is typical of children that feel themselves criticized and controlled (Tab. II).

\section{Qualitative analysis of the family drawing test}

The results were qualitatively analyzed, according to the following parameters:

1) High valuation of the family member;

2) Identification;
3) Underestimation of himself;

4) Underestimation of the brothers;

5) Domestic relationships;

6) Self-perception.

\section{Juvenile idiopathic arthritis}

- High valuation of the father: $50 \%$ of the sample indicated the father as the most important person in the family.

- Identification with figures of the domestic environment: $55 \%$ of the sample indicated the brother; $20 \%$ the father; $10 \%$ the mother; $15 \%$ other parental figures.

- Underestimation of himself: $70 \%$ of the subjects underestimated themselves.

- Underestimation of the brothers: $40 \%$ of the sample underestimated their brothers and/or their sisters.

- Domestic relationships: $70 \%$ of the sam-

Table II - Distribution of percentage of frequencies for juvenile idiopathic arthritis, enuresis, cleft palate (Machover Test).

\begin{tabular}{|c|c|c|c|c|c|}
\hline Item & Subitem & $\begin{array}{l}\text { Juvenile } \\
\text { idiopathic } \\
\text { arthritis } \\
\end{array}$ & Enuresis & $\begin{array}{l}\text { Cleft } \\
\text { palate }\end{array}$ & $\begin{array}{l}\text { Statistic } \\
\text { significancy }\end{array}$ \\
\hline \multirow{2}{*}{ Identification } & SAME SEX (Good identification) & $75 \%$ & $99.5 \%$ & $100 \%$ & $P<0.003$ \\
\hline & OPPOSITE SEX (Poor identification) & $25 \%$ & $0.5 \%$ & - & $P<0.002$ \\
\hline \multirow{3}{*}{ Head } & BIG HEAD (Need of communication) & - & $14 \%$ & - & $\mathrm{P}<0.003$ \\
\hline & $\begin{array}{l}\text { BELT THAT DIVIDE THE WAIST } \\
\text { (Lack of integration between sexuality } \\
\text { and affectivity) }\end{array}$ & - & - & - & $P<0.005$ \\
\hline & RIGID BODY (Difficulty of autonomy) & - & - & $50 \%$ & $P<0.003$ \\
\hline \multirow{4}{*}{ Eyes } & BIG EYES WITH PUPILS (Control) & - & $23 \%$ & - & $P<0.001$ \\
\hline & CLOSED EYES (Narcisism) & $50 \%$ & $0.05 \%$ & $80 \%$ & $P<0.002$ \\
\hline & $\begin{array}{l}\text { LITTLE EYES WITH PUPILS } \\
\text { (Negation) }\end{array}$ & - & $0.04 \%$ & - & $P<0.003$ \\
\hline & $\begin{array}{l}\text { EYES WITHOUT PUPILS } \\
\text { (Emotional immaturity) }\end{array}$ & - & $11 \%$ & - & $P<0.001$ \\
\hline Mouth & CLOSED MOUTH (desire of approval) & - & $29 \%$ & $50 \%$ & $P<0.002$ \\
\hline \multirow{5}{*}{$\begin{array}{l}\text { Upper limbs } \\
\text { and hands }\end{array}$} & LONG ARMS (Aggressiveness) & - & $0.12 \%$ & - & $P<0.004$ \\
\hline & COURT ARMS (Lack of self-esteem) & - & $0.04 \%$ & - & $P<0.002$ \\
\hline & $\begin{array}{l}\text { RIGID ARMS FIXED TO THE BODY } \\
\text { (Liabilities) }\end{array}$ & - & $0.90 \%$ & - & $P<0.001$ \\
\hline & ABSENT HANDS (Inadequacy) & - & $0.02 \%$ & - & $P<0.005$ \\
\hline & HANDS WITH GLOVES (Anxiety) & - & $0.04 \%$ & - & $P<0.004$ \\
\hline \multirow{5}{*}{ Legs and feet } & LONG LEGS (Autonomy) & - & $0.05 \%$ & - & $P<0.005$ \\
\hline & $\begin{array}{l}\text { SHORT LEGS } \\
\text { (Psycho-physical immobility) }\end{array}$ & - & $11 \%$ & - & $P<0.005$ \\
\hline & $\begin{array}{l}\text { STRETCHED LEGS } \\
\text { (Difficulty of autonomy) }\end{array}$ & - & - & $30 \%$ & $P<0.004$ \\
\hline & WITHOUT LEGS (Lack of support) & - & $0.04 \%$ & - & $\mathrm{P}<0.002$ \\
\hline & $\begin{array}{l}\text { FEET IN OPPOSITE DIRECTION } \\
\text { (Ambivalence) }\end{array}$ & $50 \%$ & - & - & $P<0.003$ \\
\hline
\end{tabular}


ple showed a tendency to be dependent and insecure, and to live the domestic relationships with a certain affective distance. There was neither physical nor visual contact among the members.

- Self-perception: $70 \%$ of the subjects showed an inadequate perception of himself and an aggressive behavior designed with a heavy line.

\section{Patients affected by enuresis}

- Enhancement of the father figure: $58 \%$ of the males, $30 \%$ of the females enhanced the father figure.

- Identification with figures of the domestic environment: the males have indicated: father $(33 \%)$, brother $(33 \%)$, other parental figures (34\%); the females indicated: father $(10 \%)$, sister $(40 \%)$, other parental figures $(50 \%)$.

- Underestimation of himself: $40 \%$ of the subjects underestimated theirselves.

- Underestimation of the brothers: $40 \%$ of the sample underestimated brothers or sisters.

- Domestic relationships: $50 \%$ of the subjects have manifested a tendency to be dependent and insecure and to feel repressed from the domestic environment drawing in the inferior part of the sheet.

- Self-perception: $70 \%$ of the subjects have shown an inadequate perception of him- self and an aggressive behavior (marked draws).

\section{Children with cleft palate and lips}

- Enhancement of the father figure: $45 \%$ of the males and $55 \%$ of the females has pointed out the father as the most important person in the family.

- Identification with figures of the domestic environment: the males have indicated: the father $(25 \%)$, the brother $(45 \%)$, other parental figures $(30 \%)$; the females have indicated: the father $(20 \%)$, the sister $(30 \%)$, other parental figures $(50 \%)$.

- Underestimation of himself: $60 \%$ of the subjects underestimated themselves.

- Underestimation of the brothers: $40 \%$ of them underestimated their brothers or sisters.

- Domestic relationships: $70 \%$ of the sample has manifested a tendency to be dependent and insecure and to feel repressed from the family environment drawing at the bottom of the sheet.

- Self-perception: $70 \%$ of the subjects have shown an inadequate perception of himself and an aggressive behavior (marked draws) (Tab. III).

Most of examined children underestimate himself/herself, failing to draw himself or drawing himself as last. More frequently they manifest a tendency to be dependent

Table III - Distribution of percentage of frequencies for juvenile rheumatoid arthritis, enuresis, cleft palate (Corman Test).

\begin{tabular}{|c|c|c|c|c|c|c|c|c|c|}
\hline Item & Subitem & Characters drawn & $\begin{array}{l}\text { Juver } \\
\text { rheur } \\
\text { arthri }\end{array}$ & toid & Enur & sis & $\begin{array}{l}\text { Cleft } \\
\text { palat }\end{array}$ & & $\begin{array}{l}\text { Statistic } \\
\text { significancy }\end{array}$ \\
\hline \multirow{7}{*}{$\begin{array}{l}\text { Valued } \\
\text { figure }\end{array}$} & \multirow{2}{*}{$\begin{array}{l}\text { Evaluation of the } \\
\text { father }\end{array}$} & & M & $\mathbf{F}$ & $M$ & $\mathbf{F}$ & M & $\mathbf{F}$ & \\
\hline & & & $58 \%$ & $30 \%$ & $50 \%$ & $50 \%$ & $45 \%$ & $55 \%$ & $P<0.003$ \\
\hline & \multirow{5}{*}{$\begin{array}{l}\text { Identification with } \\
\text { other domestic } \\
\text { figures }\end{array}$} & Father & $33 \%$ & $10 \%$ & $20 \%$ & & $25 \%$ & $20 \%$ & $P<0.005$ \\
\hline & & Mother & - & - & $10 \%$ & & - & - & $P<0.002$ \\
\hline & & Brother & $33 \%$ & - & $55 \%$ & & $45 \%$ & - & $P<0.005$ \\
\hline & & Sister & - & $40 \%$ & - & & - & $30 \%$ & $P<0.001$ \\
\hline & & Other figures & $34 \%$ & $50 \%$ & $15 \%$ & & $30 \%$ & $50 \%$ & $P<0.001$ \\
\hline \multirow{2}{*}{$\begin{array}{l}\text { Devalued } \\
\text { figure }\end{array}$} & Himself & & \multicolumn{2}{|l|}{$40 \%$} & $70 \%$ & & \multicolumn{2}{|l|}{$60 \%$} & $P<0.001$ \\
\hline & Brother/sister & & $40 \%$ & $40 \%$ & $40 \%$ & & $40 \%$ & $40 \%$ & $P<0.004$ \\
\hline \multirow{2}{*}{$\begin{array}{l}\text { Position of } \\
\text { the subject }\end{array}$} & Family relations & $\begin{array}{l}\text { Dependence on the } \\
\text { environment }\end{array}$ & \multicolumn{2}{|l|}{$50 \%$} & $70 \%$ & & \multicolumn{2}{|l|}{$70 \%$} & $P<0.002$ \\
\hline & Self-perception & $\begin{array}{l}\text { Inadequate } \\
\text { perception of the } \\
\text { Self }\end{array}$ & \multicolumn{2}{|l|}{$70 \%$} & $70 \%$ & & \multicolumn{2}{|l|}{$70 \%$} & $P<0.005$ \\
\hline
\end{tabular}


and insecure and to feel repressed from the family environments, drawing themselves in the inferior part of the sheet. Furthermore, most of the children showed an inadequate perception of himself and an aggressive behavior, drawing themselves with a heavy line.

Most of patients affected by JIA perceives the environment in a stressful way and show not to have the defenses to cope it; in the $70 \%$ of the family drawing tests there were no physical or visual contact between members of the family; it would mean there is an affective distance between parents and children. Lastly, children with JIA potentially assume an attitude of submissiveness and passiveness toward the environments, showing ambivalent feelings related to the indecision to advance, to demote, to run a way or to be firm (the $50 \%$ of those children draws feet in opposite directions).

\section{DISCUSSION}

The analysis of the Graphic Projective Tests demonstrated that children affected by JIA did not introduce peculiar pathological traits of personality compared to pathologies like enuresis and cleft lip and palate. It means they might have an aptitude to develop a psychological disorder, not a psychopathological one (11).

Nevertheless psychological distress regards the image of himself and his own body scheme and a delay is noticed in the affective maturation most of the time linked to a feeling of low self-esteem (12). Especially, children with juvenile idiopathic arthritis show a delay in the affective maturation and a difficulty in the sexual identification; the $25 \%$ of the sample draws a figure of the other sex that indicates inadequate gender identification. Moreover, those children reveal difficulty in the contact with the external world; in fact, most of the sample draws a figure with closed eyes and omits to draw hands and feet. Children with JIA perceive the environments in a stressful way, without any contact between members of the family and with an affective distance between parents and children.
Lastly, children with JIA potentially assume an attitude of submissiveness and passiveness in comparison to the environments, getting ambivalent feelings related to the indecision to advance or demote, to run a way or to be firm (the half part of those children draws feet in opposite directions).

From the comparison of the three pediatric groups it is interesting to notice that children affected by enuresis show mainly a deep dependence on the environment, low self-esteem and self-efficacy. They tend to underestimate himself omitting to draw themselves and identifying themselves with figures of the domestic environments, preferring denial like defense mechanism in a stressful situation (13).

Children affected by enuresis show the need of social relationship and not to have autonomy. They underestimate themselves as well and they have a really low-esteem. Previous studies have already showed the psychological and the psychiatric issues linked to urinary incontinence. The outcome of this study was to recommend a psychological screening for all children in all settings with enuresis and/or daytime urinary and/or fecal incontinence (14).

Children with cleft lip and palate show not to have autonomy and support and have lots of difficulties with the external world. More than half of them draw themselves at the bottom of the sheet that indicates a deep inhibition and introversion (15).

Collett et al. found out as well that children with orofacial clefts and their parents show worse psychosocial adaptation than controls, and that social-emotional deficits may become apparent in older-school age children, and the preschool might be an optimal time for preventive intervention (16). Lastly, those children reveal slight aggressive traits (the more than half has a heavy line), and a devaluation of him; in fact, they omit drawing themselves.

It's interesting to notice that all children show their discomfort through eyes drawing. Children suffering from enuresis draw closed eyes or eyes without pupils; children with JIA and with cleft lip and palate draw faces with closed eyes. 
In those children the greater difficulty is noticed in the contact with the external world, which make them to turn down on themselves.

Fuchs et al. show the benefits of a psychological intervention in children affected by JIA, compared to those that didn't receive it and what is the best moment to start the psychological treatment (17).

Therefore, it is easy to point out a situation of discomfort, that if not treated immediately, it could become chronic and become an emotional and behavioral disease (Tab. IV).

\section{CONCLUSIONS}

Considered the emerged results it is been pointed out that children with JIA have good sexual identification, like enuretic children and the children with cleft lip and palate. Although it has been noticed some difficulties to integrate sexuality and affectivity.

They have difficulties with the outside world, inadequate self-perception, environmental insecurity and dependence, and they present devaluation of themselves like enuretic and cleft lip and palate children. The greater difficulty in the contact with the external world, and inadequate perception of himself, can lead to abnormalities in the development of the pediatric patient. The difficulties with the outside world, the devaluation of themselves, the inadequate self-perception, according to the data present in literature, can became risk to manifest emotional problems such as anxiety, depression, aggressiveness, and behavioral difficulties, for instance, social withdrawal or relational difficulty. This risk is much more like to happen especially when young patients are subject to hospitalizations (18). In children with chronic pathologies, it exists the risk of the onset of psychological problems that might become chronic and become real psychopathological symptoms (19).

Usually, psychological discomforts are treated as personality traits, and therefore they are not identified as psychic and not taken into account in the psychic development of the child.

Identifying those psychological problems and treating them with psychological intervention could avoid the raise of psychological disease in adulthood.

Table IV - Psychological aspects in juvenile idiopathic arthritis's, enuretic's and cleft palate's samples.

\begin{tabular}{|c|c|c|c|}
\hline Items & $\begin{array}{l}\text { Juvenile idiopathic } \\
\text { arthritis }\end{array}$ & Enuresis & Cleft palate \\
\hline \multicolumn{4}{|c|}{ Human Figure Drawing Test } \\
\hline $\begin{array}{l}\text { Self-perception and social } \\
\text { perception }\end{array}$ & $\begin{array}{l}\text { Difficulty in the } \\
\text { identification; ambivalent } \\
\text { feelings of dependence } \\
\text { and autonomy }\end{array}$ & $\begin{array}{l}\text { Need of social } \\
\text { relationships; lack of } \\
\text { autonomy }\end{array}$ & $\begin{array}{l}\text { Lack of autonomy; need of } \\
\text { support }\end{array}$ \\
\hline \multicolumn{4}{|l|}{ Family Drawing Test } \\
\hline Enhancement of the father & Enhancement of the father & Enhancement of the father & Enhancement of the father \\
\hline $\begin{array}{l}\text { Identification with himself/ } \\
\text { herself or with members of } \\
\text { the family }\end{array}$ & $\begin{array}{l}\text { Identification with other } \\
\text { members of the family, not } \\
\text { with himself/herself }\end{array}$ & $\begin{array}{l}\text { Identification with other } \\
\text { members of the family, not } \\
\text { with himself/herself }\end{array}$ & $\begin{array}{l}\text { Identification with other } \\
\text { members of the family, not } \\
\text { with himself/herself }\end{array}$ \\
\hline $\begin{array}{l}\text { Enhancement of himself/ } \\
\text { herself }\end{array}$ & $\begin{array}{l}\text { Underestimation of } \\
\text { himself/herself }\end{array}$ & $\begin{array}{l}\text { Underestimation of } \\
\text { himself/herself }\end{array}$ & $\begin{array}{l}\text { Underestimation of } \\
\text { himself/herself }\end{array}$ \\
\hline $\begin{array}{l}\text { Enhancement of brothers/ } \\
\text { sisters }\end{array}$ & $\begin{array}{l}\text { Underestimation of } \\
\text { brothers/sisters }\end{array}$ & $\begin{array}{l}\text { Underestimation of } \\
\text { brothers/sisters }\end{array}$ & $\begin{array}{l}\text { Underestimation of } \\
\text { brothers/sisters }\end{array}$ \\
\hline Family relationships & Dependence on family & $\begin{array}{l}\text { Feelings of coercion from } \\
\text { family }\end{array}$ & $\begin{array}{l}\text { Repression and aptitude of } \\
\text { dependence }\end{array}$ \\
\hline Self-perception & $\begin{array}{l}\text { Himself/herself as } \\
\text { inadequate; aggressive } \\
\text { behavior }\end{array}$ & No good self-perception & No good self-perception \\
\hline
\end{tabular}




\section{REFERENCES}

1. Pinquart M, Shen Y. Depressive symptoms in children and adolescents with chronic physical illness: an updated meta-analysis. J Pediatr Psychol. 2011; 36: 375-84.

2. Carone AR, D'Amore S, Albanese L, Craig F, Scagliusi P, D'Amore M. Hospital anxiety and depression. Reumatismo. 2007; 59: 304-15.

3. Carone AR, Goffredo S, Clemente R, Craig F. Problematiche psicologiche nei pazienti con labiopalatoschisi ed enuresi notturna. Med Psicosom. 2010; 5: 11-3.

4. Manna G, Como MR. Le tecniche grafiche come strumento di valutazione del trauma infantile. Milano: Franco Angeli Ed. 2010.

5. Machover K. Personality projection in the drawing of the humane figure. Springfield: C. Thomas. 1949.

6. Corman L. Le test du dessin de famille dans la pratique médico-pédagogique. Paris: Presses Universitaires de France. 1970.

7. Oliverio Ferraris A. Il significato del disegno infantile. Torino: Boringhieri; 1975.

8. Crotti E, Magni A. Non sono scarabocchi, come interpretare i disegni dei bambini. Novara: Oscar Mondatori. 2002.

9. Passi Tognazzo D. Metodi e tecniche nella diagnosi di personalità. Firenze: Giunti. 1991.

10. Carlino Bandinelli A, Manes S. Il disegno del bambino in difficoltà. Milano: Franco Angeli Ed.; 2012.

11. Russo E, Trevisi E, Zulian F, Battaglia MA, Viel D, Facchin D, et al. Psychological profile in children and adolescents with severe course Juvenile Idiopathic Arthritis. Sci World J. 2012; 2012: 841375 .
12. Stevanovic D, Susic G, Health-related quality of life and emotional problems in juvenile idiopathic arthritis. Qual Life Res. 2013; 22: 60712.

13. Carone Craig AR, Danese M, Bellintani C, Farronato G. Problematiche psicologiche nelle affezioni da Artrite Reumatoide Giovanile. $39^{\circ}$ Congresso Nazionale SIR (Società Italiana di Reumatologia), Bari 6-9 Novembre 2002.

14. Von Gontard A, Baeyens D, Van Hoecke E, Warzak WJ, Bachmann C. Psychological and psychiatric issues in urinary and fecal incontinence. J Urol. 2001; 185: 1432-6.

15. Abd-Elsayed AA, Delgado SV, Livingstone M. Self-image perception of 171 children and adolescents with cleft lip and palate from 22 countries. Ochsner J. 2013; 13: 204-7.

16. Collett Br, Cloonan YK, Speltz ML, Anderka M, Werler MM. Psychosocial functioning in children with and without orofacial clefts and their parents. Cleft Palate Craniofac J. 2012; 49: 397-405.

17. Fuchs CE, Van Geelen SM, Hermans HJ, Van De Puttle EM, Van Geel R, Sinnema G, et al. Psychological intervention for adolescents with juvenile idiopathic arthritis: for whom and when? J Rheumatol. 2013; 40; 528-34.

18. Cousino Mk, Hazen RA. Parenting stress among caregivers of children with chronic illness: a systematic review. J Pediatr Psychol. 2013; 38: 809-28.

19. Eccleston C, Palermo TM, de C Williams AC, Lewandowski A, Morley S, Fisher E, et al. Psychological therapies for the management of chronic and recurrent pain in children and adolescents. Cochrane Database Syst Rev. 2012; 12: CD003968. 